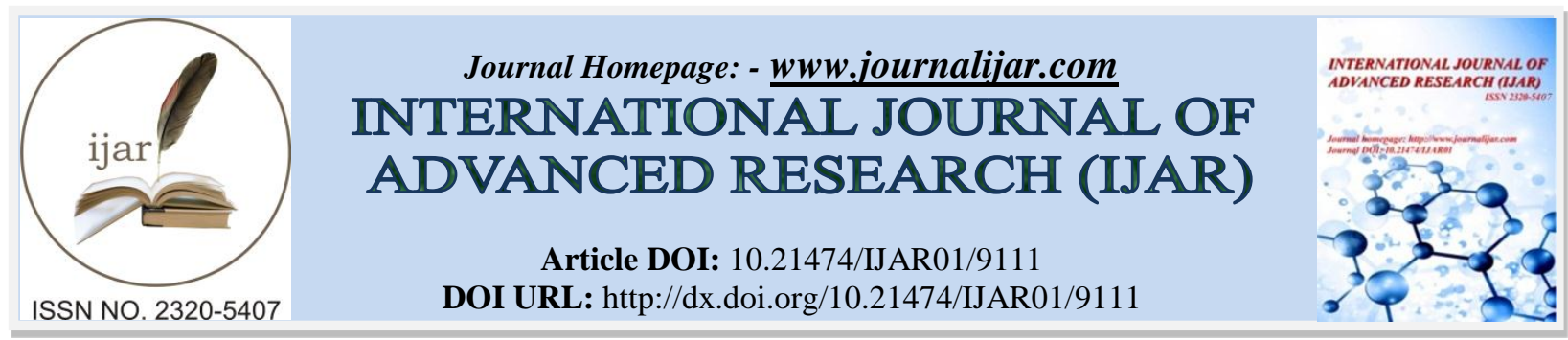

RESEARCH ARTICLE

\title{
PREPARATION AND IN VITRO EVALUATION OF OPTIMIZED FORMULATION OF BI- LAYERED FLOATING TABLET OF SUCRALFATE AND METOPROLOL SUCCINATE.
}

Sreedhar Ranjan Das, Dr. Bibhuti BhusanPanigrahi and Dr. ManojKumar.Pani.

PG Department of Pharmaceutics, Indira Gandhi Institute of Pharmaceutical Sciences, Bhubaneswar.

\section{Manuscript Info}

Manuscript History

Received: 22 March 2019

Final Accepted: 24 April 2019

Published: May 2019

Key words:-

Sucralfate, Metoprolol Succinate, Bilayered Floating Tablet, GRDDS.

\begin{abstract}
Objective: The present study based upon the preparation and in vitro evaluation of optimized Bi layered floating tablet (OSFMS) having tablet weight of $400 \mathrm{mg}$.(214.88 mgof sucralfate \& $186 \mathrm{mg}$ of Metoprol succinate). Method: Selection of the formulation, pre compression study, preparation of tablet and in vitro evaluation of tablet. Result: In presence of Lactose MFL, MCC PH 101, Sodium Bicarbonate, Polysorbate 80, Cross povidone of majore amount in Sucralfate layer and in presence of HPMC K 100 M, Sodium Bicarbonate, Eudragit RSPO, Na CMC ,Sodium alginate, HPC, Ethyl Cellulose of majore amount in Metoprolol Succinate layer it produce (OSFMS) tablet having weight of $400 \mathrm{mg}$. (214.88 mgof Sucralfate \& $186 \mathrm{mg}$ of Metoprol succinate) produced average drug release $99.92 \%$ and DT of Sucralfate was $1.04 \mathrm{~min}$ at acid medium of stomach and TFT of Metoprol Succinate at upper intesine was > 24hours. Conclusion: The optimized formulation of Sucralfate and Metoprolol Succinate (OSFMS) may be considered as a better formulation as Gastro Retaintive Drug Delivery System..
\end{abstract}

Copy Right, IJAR, 2019,. All rights reserved.

\section{Introduction:-}

Bi-Layered tablet contain immediate and sustained release layer ${ }^{1}$ The incorporated drug remain in gastric region for several hours and produce prolong gastric resistance time and improve bioavailability. It reduce drug waste and enhance the solubility of drug $^{2}$. The drug release slowly at desired rate and increase GRT and better control of fluctuations in plasma drug concentration ${ }^{3}$

Peptic Ulcer Disease [PUD] during pregnancy occurs due to imbalance between digestive juice in stomach and duodenum. It also occurs due to bacterial infections called Helico bacterial Pyrolli .(H.Pyroli). PUD during pregnancy occurs heart burn,abdominalpain,weight loss, Black and deep coloured stool etc ${ }^{4}$

Sucralfate (Sucrose Octasulphate + Aluminium Hydroxide) is an effective Antacid and $\mathrm{H}_{2}$ receptor antagonist implemented for PUD. Sucrose octasulphate react with HCL produce viscous sticky substance that bind with ulcer site and adhere with ulcerated tissue. It protect ulcer against hydrogen ion back diffusion., pepsin, and bile and promote ulcer healing. Aluminium Hydroxide neutralise gastric acid ${ }^{5}$ It can be administrated in pregnancy and lactation $^{6}$ 
According to National High Blood Pressure Education Programme Working Group on High Blood Pressure ,7 Gestational Hypertension is referred as Pregnancy Induced Hypertension (PIH).It is a condition of High Blood Pressure during pregnancy. It leads to serious condition called Preeclampsia or Toxaemia after 20 weeks of pregnancy $^{8}$

Metoprolol Succinate is a B-Blocker used to block the action' ${ }^{9}$ of certain natural chemicals ; Epinephrine that affect heart and blood vessel and lower heart rate. It is effective for treatment of blood pressure in pregnancy and lactation

${ }^{10}$.Having maintenance dose 100-200 mg daily in empty stomach with $200 \mathrm{ml}$ of water.11

Both Sucralfate and Metoprolol succinate produce minor drug interaction in pregnancy and lactate mother.12

The objective of present research based upon the preparation and in vitro evaluation of optimized Bi layered floating tablet (OSFMS) having tablet weight of $400 \mathrm{mg} .(214.88 \mathrm{mgof}$ sucralfate \& $186 \mathrm{mg}$ of Metoprol succinate and to prove as a better formulation as Gastro Retaintive Drug Delivery System..

MATERIALS AND METHODS:

2.1-Selection of formulation of Optimized Sucralfate and Metoprolol Succinate (OSFMS) Bi Layered Floating Tablet.

Table1:Composition of formulation of Optimized Sucralfate and Metoprolol Succinate (OSFMS) Bi Layered Floating Tablet

\begin{tabular}{|c|c|c|c|c|}
\hline SL No & INGREDIENTS & $\begin{array}{l}\text { Quantity } \\
\text { Ingredients in mer } \\
\text { OSF (Optimized } \\
\text { Sucralfate Layer) }\end{array}$ & INGREDIENTS & $\begin{array}{l}\text { Quantity per } \\
\text { Ingredients in mg } \\
\text { OMSF (Optimized } \\
\text { Metoprolol } \\
\text { Succinate Layer) }\end{array}$ \\
\hline 1 & SUCRALFATE & 100 & $\begin{array}{l}\text { METOPROLOL } \\
\text { SUCCINATE }\end{array}$ & 50 \\
\hline 2 & CROSS POVIDONE & 7 & HPMC K 100 M & 25 \\
\hline 3 & AEROSIL & 1 & $\begin{array}{l}\text { SODIUM } \\
\text { BICARBONATE }\end{array}$ & 15 \\
\hline 4 & LACTOSE MFL & 31.25 & AEROSIL & 3 \\
\hline 5 & MCC PH101 & 43.575 & EUDRAGIT-RSPO & 20 \\
\hline 6 & SODIUM BICARBONATE & 15 & EUDRAGIT-RLPO & 7.5 \\
\hline 7 & POLYSORBATE 80 & 7 & EUDRAGIT-RS100 & 5 \\
\hline 8 & HPC-L & 5 & $\mathrm{Na} \mathrm{CMC}$ & 17.5 \\
\hline 9 & MAGNESIUM STEARATE & 3.75 & $\begin{array}{l}\text { SODIUM } \\
\text { ALGINATE }\end{array}$ & 15 \\
\hline 10 & SUNSET YELLOW $(0.25 \%)$ & 0.3125 & $\mathrm{HPC}$ & 12.5 \\
\hline 11 & PURIFIED WATER & qs & $\begin{array}{l}\text { ETHYL } \\
\text { CELLULOSE }\end{array}$ & 10 \\
\hline & TOTAL WEIGHT & 214 & PVPK -90 & 2.5 \\
\hline 12 & & & TALC & 3 \\
\hline 13 & & & IPA & Q.S \\
\hline 14 & & & PURIFIED WATER & Q.S \\
\hline 15 & & & TOTAL WEIGHT & 186 \\
\hline
\end{tabular}

\section{2-Flow properties of lubricated granules.}

The lubricated granules obtained from wet granulation of Sucralfate and Metoprolol Succinate with different excipients are evaluated for flow properties like bulk density, tapped density, compressibility index, Hausner's ratio and angle of repose

\subsection{1-Bulk density and Tapped density (g/ml):}

The previously weighed pure drug or granules (W) were placed separately into a graduated measuring cylinder and the initial (bulk) volume $\left(\mathrm{V}_{\mathrm{B}}\right)$ was noted. It was placed in the tapped density tester USP and subjected to constant tapping at a rate of 200drops/min until the difference between the initial and final volumes should be less than $2 \%$. It 
was recorded as the final (tapped) volume $\left(\mathrm{V}_{\mathrm{T}}\right)$ and various flow properties were calculated with the following formulae.

Bulk density, $\rho B=\frac{W}{V B} \quad$ Tapped density, $\rho T=\frac{W}{V T}$

\subsection{2-Compressibility Index:}

It was calculated by using the following formula

Carr's Index or Compressibility Index $(\mathrm{CI})=1-\frac{\rho \mathrm{B}}{\rho \mathrm{T}} * 100$

The CI value below $15 \%$ indicates good flow of the powder and above $30 \%$ indicates poor flow property of the powder.

2.2.3-Hausner's Ratio: It is calculated by the following formula;

Hausner's Ratio $=\frac{\rho T}{\rho B}$

The Hausner's ratio below 1.25 indicates good flow property and above 1.25 indicates poor flow property of the powder.

2.2.4Angle of Repose $(\boldsymbol{\Theta})$ : It was determined by using a funnel whose tip was fixed at a constant height $(\mathrm{H})$ of $2.5 \mathrm{~cm}$ from horizontal surface. The granules and the powder were passed separately through the funnel until the tip of the conical pile touches the tip of the funnel. The radius of the base of the conical pile is measured as R (cm). It is determined with the formula;

Angle of repose $(\theta)=\operatorname{Tan}^{-1}$ (height /radius).

\section{3- Acclerated stability study is done of lubricated granules.}

Acclerated Stability study is done of $10 \mathrm{gm}$ of each optimized batch. Acclerated stability study is done of lubricated granules of each formulations of Sucarlfate and Metoprolol Succinate at at $45^{\circ} \mathrm{C}$ and $75 \% \mathrm{RH}$ for a period of 3 months. The tablets were packed in $85 \mathrm{~mm}$ HDPE bottles with an oxygen adsorbent, and a desiccant containing silica gel with cotton as filler. The granules were withdrawn after the regular interval of stability period, and evaluated for physical properties .

\section{4-Flowproperties of lubricated granuls after 90 days of stability studies.}

Compairision study is done between initial parameters of flow properties of granules and granules after 90 days of stability study.of Sucralfate and Metoprolol Succinat

\section{5--Preparation of Bi-layered tablets of OSFMS:}

Following the optimizied formulation Sucralfate layer and Metoprolol Succinate layer, Bilayered Floating tablets were prepared.The Bi-Layered tablets of Sucralfate and Metoprolol Succinate (OSFMS) were compressed using $13.1 \mathrm{~mm}$ round concave punches using a Bi-Layered Tablet Compression Machine. The granules of Metoprolol Succinate were placed first and pre-compressed with slight hardness of about 4-5KP. Then the granules of Sucralfate were placed and compressed with a final hardness of about 12-14 KP. The compression of Bi-Layered Tablet is based upon Composition of optimized Sucralfate layer and composition of optimized Metoprolol Succinate layer,

\section{6- The post compressial parameters ;}

\subsection{1-Weight variation:}

Twenty tablets were collected randomly and the average weight and individual weight was calculated. The $\%$ weight variation was calculated with the following formula.

$\%$ Weight variation $=$ Average weight-individual weight/individual weight $\mathrm{x} 100$

2.6.2-Thickness:

The thickness of the ten tablets was measured in mm by using Vernier calipers.

\subsection{3-Hardness:}

The hardness of the ten tablets was measured by using Varian V K200 Tablet Hardness Testerand is given in the units of KP.

\subsection{4-Friability:}


Ten tablets were carefully dedusted prior to testing and weighed accurately (Wo). The tablets were placed in the drum of Roche Friabilator (USP). The drum was rotated for 100 times at a speed of $25 \mathrm{rpm}$. The tablets were collected, re-dedusted and accurately weighed (W1). It is calculated form the following formula;

$\%$ Friability $=1-\frac{W 1}{W 0} * 100$

2.6.5-Disintegration Test:

The disintegration study was performed for sucralfate tablets by using disintegration apparatus Thermonik DT Tester (USP). For this water was used as the disintegration medium. 6 tablets were placed in 6 tubes of the disintegration apparatus. The time ( $\mathrm{min})$ taken for the tablets to disintegrate was noted.

2.6.6-Floating lag time (FLT):

The MS tablets were placed in a beaker containing $250 \mathrm{ml}$ of $0.1 \mathrm{~N} \mathrm{HCl}$ and the time (sec) required to float the tablet was observed and recorded as FLT.

2.6.7-Total floating time (TFT):

The time (hr) up to which the MS tablet remains buoyant was noted and recorded as TFT.

2.6.8-Swelling index of Metoprolol Succinate tablets

The previously weighed (W1) tablet was placed in USP apparatus type-I which was immersed in a bowel containing $900 \mathrm{ml}$ of $0.1 \mathrm{~N} \mathrm{HCl}$ and maintained at $37 \pm 0.2^{\circ} \mathrm{C}$. The tablets were removed from the basket at regular intervals of time (up to 8hrs with $1 \mathrm{hr}$ interval) and placed on a blotting paper to remove the excess medium (Fig 6.7). The tablet was reweighed (W2). The studies were repeated for all formulations in triplicate. The swelling index was calculated as follows:

Swelling Index = W2-W1/W1 x 100

\section{7-Determination of drug content of Sucralfate tablets:}

Ten SF tablets were weighed accurately and then crushed well in a clean motor and pestle. The powder equivalent to $25 \mathrm{mg}$ of the drug was weighed (Ws) and then transferred to a $100 \mathrm{ml}$ volumetric flask. $50 \mathrm{ml}$ methanol was added and sonicated for 5 minutes at $27^{\circ} \mathrm{C}$. Then the volume was made up to $100 \mathrm{ml}$ using methanol (V4). From this $4 \mathrm{ml}$ (V5) was transferred to a $100 \mathrm{ml}$ volumetric flask and the volume was made up to $100 \mathrm{ml}$ (V6) with $0.1 \mathrm{~N} \mathrm{HCl}(\mathrm{pH}$ 1.2). The flask was agitated for 5 minutes and then the sample was analyzed for drug content at $281 \mathrm{~nm}$ using UV Spectrophotometer. The drug content was calculated using the following formula.

\% Drug Content $=\frac{A S}{A S} * \frac{W}{V 1} * \frac{V 2}{V 3} * \frac{V 4}{W S} * \frac{V 6}{V 5} * \frac{A W}{L} * P$

Where,

$\mathrm{AS}=$ Test absorbance

$\mathrm{AS}=$ Standard Absorbance

$\mathrm{W}=$ Weight of standard drug $(25 \mathrm{mg})$

$\mathrm{V} 1=$ Volume of solvent added to standard stock solution (100ml)

$\mathrm{V} 2, \mathrm{~V} 3=$ Dilution of the standard stock solution $(4 \mathrm{ml}$ of stock solution diluted to $100 \mathrm{ml}$ with solvent)

$\mathrm{AW}=$ Average weight of the tablet $(\mathrm{mg})$

$\mathrm{L}=$ Label claim of the drug $(10 \mathrm{mg})$

$\mathrm{P}=$ Potency of sucralfate $(91.4 \%)$.

\section{8-Determination of drug content of Metoprolol Succinate tablets: :}

Ten MS tablets were weighed and crushed in a motor with pestle. The crushed powder equivalent to $100 \mathrm{mg}$ of MS (WS) was weighed accurately and transferred to a clean, dried $100 \mathrm{ml}$ volumetric flask. $50 \mathrm{ml}$ of $0.1 \mathrm{~N} \mathrm{HCl}$ was added and agitated vigorously for 10 minutes and sonicated for 4 hours. The final volume was made up to $100 \mathrm{ml}$ (V4) using $0.1 \mathrm{~N} \mathrm{HCl}$ and agitated for 5 minutes. A portion of it was centrifuged at 3000rpm for 10 minutes. The centrifuged sample was filtered through $0.45 \mu \mathrm{m}$ whatmann filter paper. $2 \mathrm{ml}$ (V5) of the filtered sample was pipetted out and transferred to a $100 \mathrm{ml}$ volumetric flask and the volume was made up to $100 \mathrm{ml}$ (V6) with $0.1 \mathrm{~N} \mathrm{HCl}$ and the flask was shaked for 5 minutes. The sample was then analyzed for the drug content at $233 \mathrm{~nm}$ using UV Spectrophotometer. The drug content was calculated using the following formula.

$\%$ Drug Content $=\frac{A S}{A S} * \frac{W}{V 1} * \frac{V 2}{V 3} * \frac{V 4}{W S} * \frac{V 6}{V 5} * \frac{A W}{L} * P$

$\mathrm{AS}=$ Test absorbance

$\mathrm{AS}=$ Standard Absorbance

$\mathrm{W}=$ Weight of standard drug (100mg) 
$\mathrm{V} 1=$ Volume of solvent added to standard stock solution $(100 \mathrm{ml})$

$\mathrm{V} 2, \mathrm{~V} 3=$ Dilution of the standard stock solution ( $2 \mathrm{ml}$ of stock solution diluted to $100 \mathrm{ml}$ with solvent)

$\mathrm{Aw}=$ Average weight of the tablet (mg)

$\mathrm{L}=$ Label claim of the drug (375mg)

$\mathrm{P}=$ Potency of metoprolol succinate $(99.83 \%)$.

\section{9- Release kinetic profile of Metoprolol Succinate:}

Mechanism of drug release from MS tablets:

Different mathematical models were applied for describing the kinetics of the drug release process from the tablets. The rate of drug release from tablets was determined by finding the best fit of the dissolution data to distinct models: zero order (eq. 1), first order (eq. 2), and mechanism of drug release from Higuchi (eq. 3)
$\mathrm{Qt}=\mathrm{k} 0 \mathrm{t}$ ..(eq. 1)
$\mathrm{Qt}=\mathrm{Q} \infty(1-\mathrm{e}-\mathrm{k} 1 \mathrm{t})$ (eq. 2)
$\mathrm{Qt}=\mathrm{kH} \mathrm{t} 1 / 2$ (eq. 3)

Where, Q $\infty$ being the total amount of drug in the matrix, $\mathrm{k} 0$ the zero order kinetic constant, $\mathrm{k} 1$ the first order kinetic constant and $\mathrm{kH}$ representing the Higuchi rate constant. The best fit model was found by using correlation coefficient values (R), using MS EXCEL.

The data obtained from in vitro dissolution studies were fitted to zero-order, first-order, and Higuchi equations. The dissolution data obtained were plotted as Time versus cumulative percent drug released as zero order, Time versus cumulative percent drug remaining as First order release kinetics, Square root of time versus cumulative percent drug released as Higuchi equation

\section{Result and discussion:-}

3.1- Flow properties of lubricated granules of Sucralfate and Metoprolol Succinate. Optimized formulations. Table-2:

\begin{tabular}{|l|l|l|l|l|l|l|}
\hline $\begin{array}{l}\text { Formulation } \\
\text { Code }\end{array}$ & $\begin{array}{l}\text { Angle of } \\
\text { Repose }(\Theta)\end{array}$ & $\begin{array}{l}\text { Bulk } \\
\text { Density } \\
(\mathrm{g} / \mathrm{ml})\end{array}$ & $\begin{array}{l}\text { Tapped } \\
\text { Density }(\mathrm{g} / \mathrm{ml})\end{array}$ & $\begin{array}{l}\text { Compressibility } \\
\text { Index }(\%)\end{array}$ & $\begin{array}{l}\text { Hausner's } \\
\text { Ratio }\end{array}$ & \%LOD \\
\hline OSF & 20.16 & 0.215 & 0.498 & 27.12 & 1.342 & 1.82 \\
\hline OMS & 21.24 & 0.218 & 0.523 & 32.57 & 1.457 & 1.94 \\
\hline
\end{tabular}

OSF- Optlmized Sucralfate layer.OSFMS- Optimized Metoprolol succinate layer.

3.2-Acclerated stability study of lubricated granules of Sucralfate and Metoprolol Succinate Optimized formulations

It shows there is no any physical or chemical changes observed after 90 days at proper temperature and relative humidity condition.

Table-2:

\begin{tabular}{|l|l|l|l|l|l|l|}
\hline GRANULES & $\begin{array}{l}\text { AFTER } \\
\text { DAYS }\end{array}$ & $\begin{array}{l}\text { AFTER 15 } \\
\text { DAYS }\end{array}$ & $\begin{array}{l}\text { AFTER 30 } \\
\text { DAYS }\end{array}$ & $\begin{array}{l}\text { AFTRER 45 } \\
\text { DAYS }\end{array}$ & $\begin{array}{l}\text { AFTER 60 } \\
\text { DAYS }\end{array}$ & $\begin{array}{l}\text { AFTER 90 } \\
\text { DAYS }\end{array}$ \\
\hline OSF & No Change & No Change & No Change & No Change & No Change & NO change \\
\hline OMS & No Change & No Change & No Change & No Change & No Change & NO change \\
\hline
\end{tabular}

OSF- Optlmized Sucralfate layer.OMS- Optimized Metoprolol succinate layer.

3.3- Flow properties of lubricated granules of Sucralfate and Metoprolol Succinate Optimized formulations after 90 days of stability studies produce following result.

Table-3:

\begin{tabular}{|l|l|l|l|l|l|l|}
\hline $\begin{array}{l}\text { Formulation } \\
\text { Code }\end{array}$ & $\begin{array}{l}\text { Angle of } \\
\text { Repose }(\Theta)\end{array}$ & $\begin{array}{l}\text { Bulk } \\
\text { Density } \\
(\mathrm{g} / \mathrm{ml})\end{array}$ & $\begin{array}{l}\text { Tapped } \\
\text { Density }(\mathrm{g} / \mathrm{ml})\end{array}$ & $\begin{array}{l}\text { Compressibility } \\
\text { Index }(\%)\end{array}$ & $\begin{array}{l}\text { Hausner's } \\
\text { Ratio }\end{array}$ & \%LOD \\
\hline OSF & 21.71 & 0.219 & 0.501 & 25.10 & 1.234 & 1.79 \\
\hline OMS & 22.34 & 0.210 & 0.524 & 31.67 & 1.405 & 1.67 \\
\hline
\end{tabular}

OSF- Optlmized Sucralfate layer. OMS- Optimized Metoprolol Succinate layer. 
3.4- Post compressional parameters OSFMS Bi layered Floating Tablet.

Table 4:

\begin{tabular}{|l|l|l|}
\hline SL. NO. & \multicolumn{1}{|c|}{ Parameter } & $\begin{array}{l}\text { Bilayered Floating Tablets of OSFMS } \\
\text { observed values }\end{array}$ \\
\hline 1 & Average Weight (mg) & $400 \pm 0.379$ \\
\hline 2 & Thickness (mm) & $5.21 \pm 0.125$ \\
\hline 3 & Hardness (KP) & $8.1 \pm 0.291$ \\
\hline 4 & \% Friability & 0.543 \\
\hline 5 & DT of Sucralfate layer in minute & $1.04 \pm 0.154$ \\
\hline 6 & $\begin{array}{l}\text { FLT of Metoprolol Succinate layer in } \\
\text { seconds }\end{array}$ & 6.45 \\
\hline 7 & TFT of Metoprolol Succinate Layer in hrs & $>24$ \\
\hline
\end{tabular}

\section{5 : Release kinetic profile of Sucralfate}

The cumulative drug release study of Sucralfate in $0.1 \mathrm{~N} \mathrm{HCl}$ from OSFMS at $281 \mathrm{~nm}$ produce averagely $99.78 \%$ drug release.

\section{6 : Release kinetic profile of Metoprolol Succinate:}

The cumulative drug release study of Metoprol succinate in $0.1 \mathrm{~N} \mathrm{HCl}$ at $233 \mathrm{~nm}$ produce produce averagely $100.06 \%$ drug release release within 20 hours.

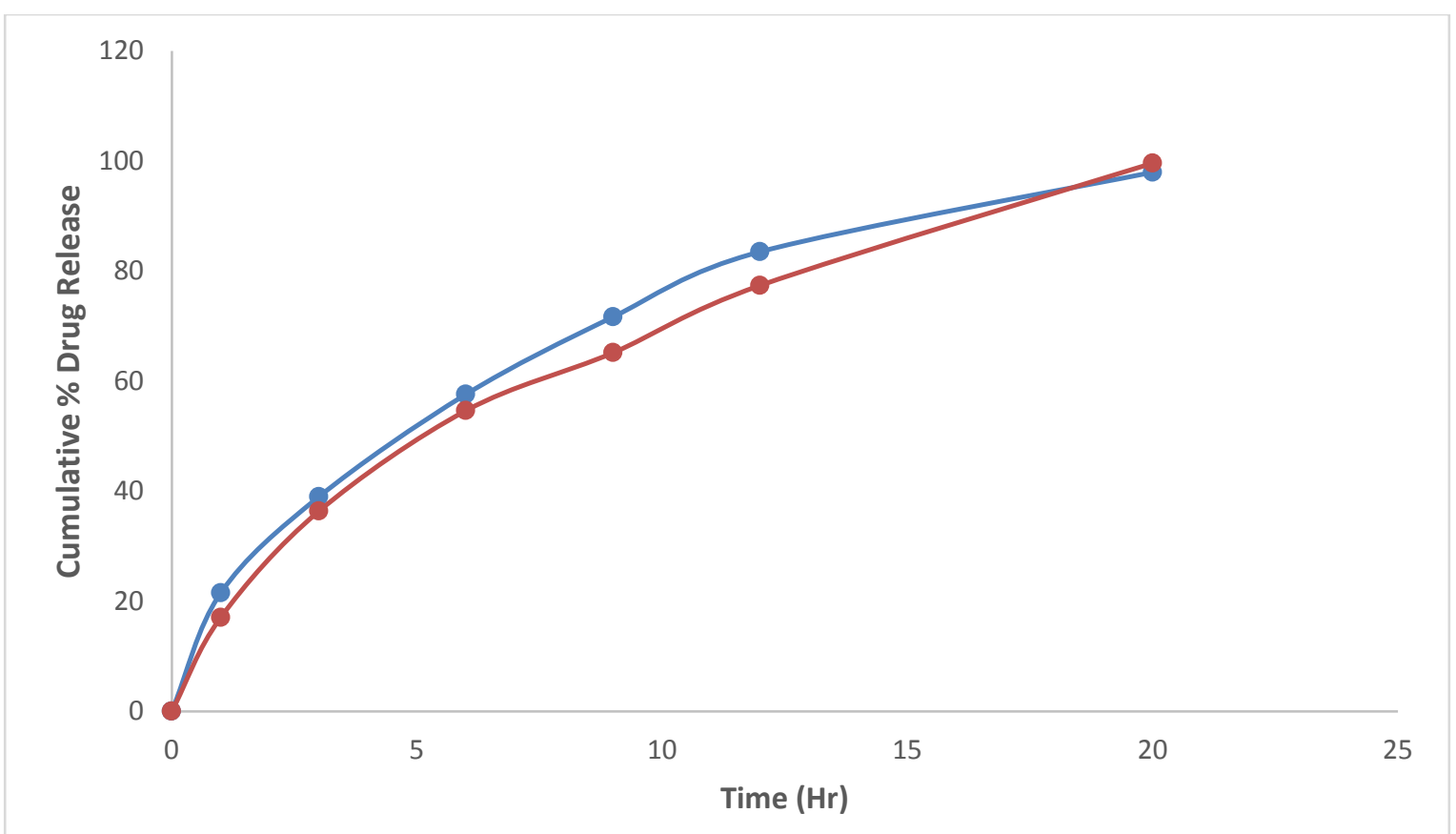

Figure-1: Cumulative drug release study of Sucralfate and Metoprolol Succinate in $0.1 \mathrm{~N} \mathrm{HCl}$ from OSFMS.

3.7-Avrage drug release of OSFMS in \% $(99.78+100.06=199.84 / 2=99.92)$

3.8- Acclerated stability study of Sucralfate and Metoprolol Succinate Optimized TabletsAfter 90 days of Accelerated stability study at proper temperature and humidity condition produce near about similar physical parameters which shows better stability of formulation.

Table-5:

\begin{tabular}{|l|l|l|l|l|l|l|}
\hline GRANULES & $\begin{array}{l}\text { AFTER } \\
\text { DAYS }\end{array}$ & $\begin{array}{l}\text { AFTER } \\
\text { DAYS }\end{array}$ & $\begin{array}{l}\text { AFTER 30 } \\
\text { DAYS }\end{array}$ & $\begin{array}{l}\text { AFTRER 45 } \\
\text { DAYS }\end{array}$ & $\begin{array}{l}\text { AFTER 60 } \\
\text { DAYS }\end{array}$ & $\begin{array}{l}\text { AFTER 90 } \\
\text { DAYS }\end{array}$ \\
\hline OSF & No Change & No Change & No Change & No Change & No Change & NO change \\
\hline
\end{tabular}




\begin{tabular}{|l|l|l|l|l|l|l|}
\hline OMS & No Change & No Change & No Change & No Change & No Change & NO change \\
\hline
\end{tabular}

\section{Conclusion:-}

After in vitro evaluation and stability studies of optimized Bi layered floating tablet (OSFMS) having tablet weight of $400 \mathrm{mg}$.(214.88 mgof sucralfate $\& 186 \mathrm{mg}$ of Metoprol succinate). can fulfil all the criteria of IP standard and ICH guideline .Sucralfate in acidic medium produce averagely $99.78 \%$ drug release .. Within 20 hours Metoprolol Succinate produce averagely $100.06 \%$ drug release release in acidic medium and identified as better formulation for further studies. The present study can generate a new scope in optimization of formulations and clinical trials and can produce better identification in Gastro Retentive Drug Delivery System.

\section{References:-}

1. Biswal B .Design development and evaluation of Trimetazidine Di hydrochloride Floating Bi-Layer M.R Tablet .IRJP $2011 ; 7$ : 92-97.

2. Garg R K ,Singhvi I. Bilayer Floating Tablet Technology : An Overview ; IJPPR 2015, 3: 302-22.

3. Kardumpala S, Chetty M, Gnanaprakash K, Venkatesh B, Sankar P. A review on Bilayer Floating Tablets. IJRPS 2013; 2:354-60.

4. HansikaK.Stomach.ulcer.duringpregnancy,October,8,2015,Available.at https://www.momjunction.com/articles/peptic-ulcer-during pregnancy.00372291\#gerf.

5. Briggs GG, Freeman RK. Drugs in pregnancy and lactation $.10^{\text {th }}$ edition. Philadeiphia.PA: Wolters Kluwer Health ; 2015.

6. Tripathy KD, Essential of Medical pharmacology. $5^{\text {th }}$ edition. Jaypee Brothers Medical Publication ; $2003: 596$.

7. Mark AB, Laura AM, Louise CK, Kurumanchi SA, Fergus PM, David RH, et al .The hypertensive disorder in pregnancy $2018 ; 19: 291-310$.

8. Hansika K.Stomach ulcer during pregnancy, Oct,8,2015;Available at https://www.momjunction.com/articles/peptic-ulcer-during pregnancy.00372291\#gerf.

9. Kirch W, Schafer-Korting M, Axthelm T,Kohier H, Mutschier E. Interaction of atenolol with furesimide and calcium and aluminium salts. Clin Phamacol Ther.1981;(30): 429-35.

10. Sweden N, Metoprol pregnancy and breastfeeding warning. Nov, 24, 2018 : Avilable in https:// www.ncbi.nlm.nih.gov/pumbed/2940080.

11. Paul B,Stephen PC, Rex NB. Metoprolol,An Updated Review of its Pharmacodynamic and Pharmacokinetic Properties, and Therapeutic Efficacy, in Hypertension, Ischaemic Heart Disease and Related Cardiovascular Disorders. 1986; 5 :75-88.

12. Regardh CG, Lundborg P, Persson BA, The effect of antacid, metoclopramide, and propantheline on the bioavilability of metoprolol and atenolol Biopharm Drug Dispos.1981;2 :79-87

\section{Acknowledgement:-}

I would like to express my special thanks of gratitude to my Guide Dr Bibhuti Bhusan Panigrahi and Co Guide Dr Monoj Kumar Pani as well as The Principal who gave me a golden opportunity to proceed on my research work on the topic which helped in enhancement of my knowledge and ability.I am really thankful to them.

Secondly i would like to thank my parents, my family and supporting staffs who helped me a lot in fulfilment of the work.

Finally i would like to thank to God for blessing of further proceed.

\section{Conflict of intrest:-}

The authors declare that there no conflict of interest regarding the study. 